\title{
Analysis of Factors that Influence Customer Loyalty in Taking People's Business Credit (KUR) at PT. Bank Sulselbar Makassar Main Branch
}

\author{
Zulkifli Jamid $^{{ }_{1}}$, Ria Mardiana² Sabir $^{3}$ \\ 1,2,3 Master of Management Hasanuddin University \\ DOI : https://doi.org/10.37531/ecotal.v3i1.112
}

\begin{abstract}
Customer loyalty is the expectation of every banking company. This study aims to analyze the effect of service, advertising, and corporate image variables on customer satisfaction. Furthermore, to analyze the effect of service variables, advertising, and company image on customer loyalty and analyze the effect of customer satisfaction variables on customer loyalty. This type of research is a quantitative research using path analysis techniques using SPSS software with path analysis techniques whose data is obtained from distributing questionnaires to 75 respondents who are people's business credit service customers. The results of the study found that service quality is always maintained, attractive advertising activities and the company's image is continuously maintained will have an impact on growing customer satisfaction so that loyalty can also be created among customers of PT. Bank Sulselbar Makassar Main Branch.
\end{abstract} Keywords : Service, Advertising, Company Image, Satisfaction, Loyalty

\footnotetext{
$\triangle$ Corresponding Author :

E-mail address: zulkiflijamid99@gmail.com (Jl. Monginsidi, Sarae, Rasanae Makassar, Indonesia)

“Received 08 December 2021, Accepted 14 December 2021, Published 24 December 2021"
} 


\section{Introduction}

The banking sector is now trying to pay more attention to the relationships that arise from a continuous marketing process in order to retain customers (Customer Relationship Marketing). The goal to be achieved is to build and improve customer loyalty and retain existing customers. Empirically, the tendency of people to be loyal to people's business credit (KUR) is based on various considerations and factors. Factors that can affect customer satisfaction and loyalty, namely service is the thing that is most prioritized by increasing the quality of services provided by the bank. The results of previous research from Assagaff (2014), Dewi et al (2014), and Anggraeni (2014) found that service quality had a positive and significant effect on customer satisfaction and loyalty. On the other hand, Purwanti, et al (2013) found that service quality and company image had no significant effect on customer satisfaction and loyalty. These findings indicate that customer satisfaction and customer loyalty to KU services, apart from being influenced by company image and service quality, have other dimensions that influence them. Especially when these dimensions, seen from the consumer's point of view.

The consumers in this study are KUR customers. They will generally assess a service received and compare it with and their wishes. Parasuraman in Hidayat, 2009). The impact is that when customers are satisfied it will be followed by loyalty (Hidayat, 2009). This means that satisfaction can be related to what is expressed by customers about their perceptions and expectations of the services obtained. While loyalty is related to what consumers do after interacting in the service process. This concept implies that customer satisfaction alone is not enough, because satisfied or dissatisfied is only one form of emotion that arises from within the customer. Meanwhile, customer loyalty is important to analyze because customer loyalty will arise after making more than one transaction at a bank.

This situation also happened to Bank Sulselbar towards one of Bank Sulselbar's services, namely people's business credit or commonly called KUR. People's Business Credit (KUR) is credit or financing to Micro, Small and Medium Enterprises (MSMEs) in the form of providing working capital and investment which is supported by guarantee facilities for productive and feasible businesses but has limitations in fulfilling the requirements set by banks.

Advertising is also a factor that can foster customer satisfaction and loyalty, by using the media to inform the public about credit quality in small segments. Novaria et al (2013) in their research found that promotion/advertising has an effect on customer satisfaction and loyalty. The next 
Zulkifli Jamid $^{\otimes}$, Ria Mardiana ${ }^{2}$ Sabir $^{3}$

Analysis of Factors that Influence Customer Loyalty in Taking People's Business Credit

DOI : $\underline{\text { https://doi.org/10.37531/ecotal.v1i2.18 }}$

factor is the image of the company, in accordance with the findings of Purnomo (2011) that the image of the company has an important role in increasing customer satisfaction and loyalty.

Various strategies are implemented by banks in achieving optimal performance, such as a study conducted (Choirunnisak, 2012) that the pick-up strategy, network development (Suherli, 2012), excellent service and providing satisfactory facilities and an effective marketing strategy for banking products to satisfy customers (Aziza, 2010). In addition to an effective business strategy, the success of the banking industry is also determined by the ability to adapt in a rapidly changing and unpredictable business environment. Thus, it is necessary to analyze environmental elements to identify any changes that can become opportunities and opportunities for companies by developing the use of information technology (Anatan, 2010). Likewise, aspects of lending, collecting third party funds and providing banking services are the core business of banking, thus banks are required to develop their business strategies at the central, regional and work unit levels.

The banking industry generally focuses on the aspect of lending by continuously improving credit quality. This makes banks continue to adhere to the precautionary principle as the basis for lending. The composition of the portfolio in lending to leading sectors should be continuously evaluated, so that any changes that occur in certain sectors can be anticipated properly to minimize the risk of bad loans. Strategic agility enables companies to flexibly respond to complex, global and dynamic environments (Sombolayuk et al., 2019).

\section{Literature Review}

Marketing that is run for companies that produce goods is certainly different from companies that produce service products such as banks. Therefore, marketing treatment of the banking world in general can be put forward as a process to create and deliver bank products and or services that aim to meet the needs and desires of customers so that customers can become loyal.(Naninsih, 2019). Having loyal customers is one of the ultimate goals of the company because customer loyalty can guarantee the longevity of banking companies in the long term. Basically customer loyalty as a person's loyalty to the services issued by the bank company. An agreement to repurchase goods or services and recommend the bank's service products to others. Customer satisfaction relies on estimates of product performance to provide value, relative to buyer expectations. Buyers are satisfied if performance matches expectations. Buyers are dissatisfied if product performance is much lower than customer expectations, Kotler and Armstrong, (2001). Customer satisfaction or dissatisfaction is shown as a person's overall feeling or attitude about a product after the product is consumed. The condition of the customers is followed by a process of evaluating the products purchased and integrated in their every consumption activity. Service is one of the factors that can affect customer satisfaction and loyalty.

Volume 3 Issue 1 (2022)

Economics and Digital Business Review

ISSN: 2774-2563 (Online) 
Zulkifli Jamid $^{\otimes}$, Ria Mardiana ${ }^{2}$ Sabir $^{3}$

Analysis of Factors that Influence Customer Loyalty in Taking People's Business Credit

DOI : $\underline{\text { https://doi.org/10.37531/ecotal.v1i2.18 }}$

Quality services refer more to efforts to provide quality, efficient and effective services, public services can be effective if the community/consumers are satisfied, the benchmark is the absence or lack of public/consumer complaints. Furthermore, Batinggi argues that to improve public services so that they are efficient and effective, the service providers should always try to improve by improving and exercising open control (Tjiptono, 2000). Assagaff (2014) in his research found that service quality can affect customer satisfaction and make customers loyal to the service company they follow. After quality service, advertising and bank image is also one that can affect customer satisfaction and loyalty. According to Kotler (2005:277) states that: "Advertising is any form of non-personal presentation and promotion of ideas, goods, or services by a particular sponsor that must be paid for. Furthermore, corporate image in marketing was initially identified as an important factor in the evaluation of services and the company as a whole (Gronroos, 1998). Apart from the situation where image is a function of accumulated consumption or purchase experienced over time, most organizations also provide a rich and complex informational environment for attracting new customers and retaining existing ones. Purwanti, et al (2013), with the topic of research on corporate image on customer satisfaction and loyalty found a link between efforts to form a good corporate image on increasing customer satisfaction and loyalty. The definition of comprehensive advertising according to Kotler, Philip and Armstrong (2012), advertising is "All forms of non-personal presentation and promotion of ideas, goods or services by a particular sponsor that requires payment".

\section{Research Method}

In this study, researchers used a quantitative approach that emphasizes the analysis of data in the form of numerical numbers that are processed by statistical methods. Basically, this quantitative approach is carried out in inferential research (in the context of testing the hypothesis) and the conclusion is that the probability of rejecting the hypothesis is zero. With the quantitative method, it will be obtained that there is a significant relationship between the variables studied. The analytical technique used in this research is path analysis technique. This research was conducted at PT. Bank Sulselbar Makassar Main Branch. The research time for data collection was carried out from September to November 2021. The population in this study were KUR credit customers of PT. Bank Sulselbar Makassar Main Branch. The research population is 75 debtors as described above. The sample in this study was 75 respondents or commonly referred to as a saturated sample (census).

\section{Research Results and Discussion}

Based on data collection carried out using a questionnaire, the relationship between variables was tested using IBM SPSS 22 software with the test results that can be seen in the path analysis model image as follows:

Volume 3 Issue 1 (2022) 
Figure 1. Path Analysis (Model II)

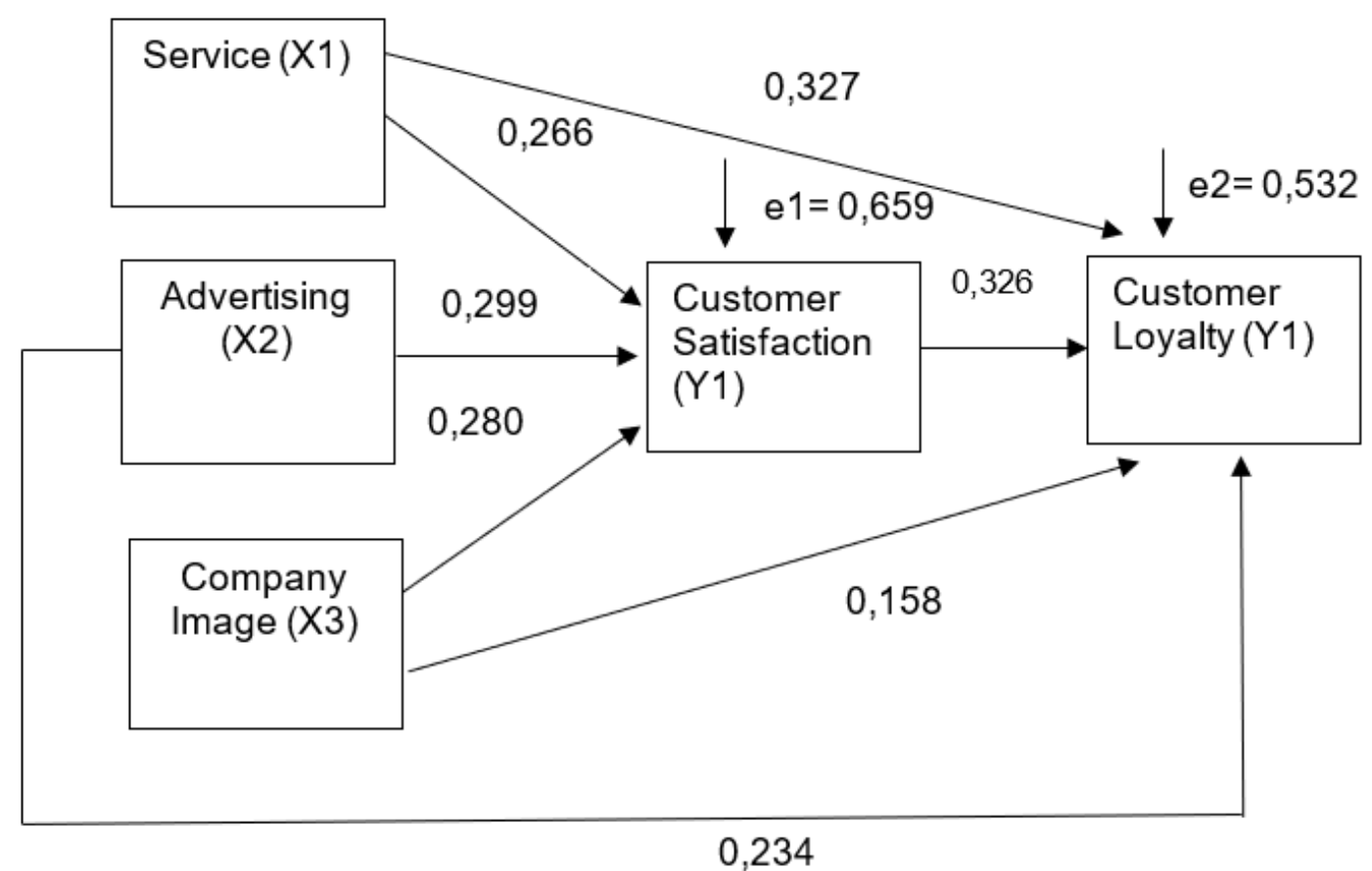

Source: SPSS Output (2021)

From the path analysis model image above, the results of the coefficient test in this study can be described as follows:

1) Analysis of the effect of $X 1$ on $Y 1$ shows a significance value of $0.031<0.05$ with a total effect of 0.144 . This indicates that the service has a significant positive effect on customer satisfaction. This makes H1 in this study accepted.

The results of this study support the results of other studies that have been carried out by Raziq Aulia (2021), Octavia (2019) and Trianah et al., (2017) which suggests that service quality is one of the factors that affect customer satisfaction. Quality of service gives impetus to customers to forge a strong bond with the company. To find out the level of customer satisfaction, it is necessary to first know the quality of service provided by the manufacturer to its customers. Customer satisfaction will arise after someone has experienced the quality of experience provided by the service provider. As a service provider, the Bank is required to fulfill customer satisfaction, which is an important matter for the Bank to pay attention to. 
Zulkifli Jamid $^{\otimes 1}$, Ria Mardiana ${ }^{2}$ Sabir $^{3}$

Analysis of Factors that Influence Customer Loyalty in Taking People's Business Credit

DOI : $\underline{\text { https://doi.org/10.37531/ecotal.v1i2.18 }}$

The results of this study are in line with the opinion of Donni Juni Priansah (2017: 196) which states that customer satisfaction is a person's feeling of pleasure or disappointment that arises after comparing the expected service performance to the expected service..

Without customers, the Bank's operations will not be able to run as they should. Thus, one strategy to increase customer satisfaction can be done by providing a means of consumer protection. For example, providing a suggestion box for customers. Where customers can submit their complaints without being afraid to be intimidated by the bank because the confidentiality is really maintained. In addition, several other strategies that can be carried out, namely services in physical form can also be applied in the form of providing physical services (facilities and infrastructure) that support consumer convenience, responsive services, and so on.

2) Analysis of the effect of $X 2$ on $Y 1$ shows a significance value of $0.008<0.05$ with a total effect of 0.305 . This indicates that advertising has a significant positive effect on customer satisfaction. This makes $\mathrm{H} 2$ in this study accepted.

The results of this study support the results of previous research conducted by (Winarti, 2016)), Faizah (2017), and Sopiyan (2020) which suggests that advertising has a significant effect on customer satisfaction. This is because advertising can create a stigma that forms customer expectations of the services or products offered by a bank. When the customer feels that there is a match between the advertisements he sees and the reality he gets using the related bank services, it will create a sense of satisfaction for him.

The results of this study are in line with the opinion of Djaslim Saladin in his research Marisa (2013) states that advertising is one of the promotional tools, usually used to direct persuasive communication to customers where this form of advertising presentation is non-personal.

In this study it was also found that, several things that make advertising have a significant effect on customer satisfaction, namely with advertisements, customers are able to obtain clear information regarding the services or products they want to use, thus creating a link to using the services and products they get from advertising. . In addition, the provision of advertising facilities on a periodic basis can also make customers tend to remember these advertisements when they need services or products that suit their needs. 
Zulkifli Jamid $^{\otimes 1}$, Ria Mardiana ${ }^{2}$ Sabir $^{3}$

Analysis of Factors that Influence Customer Loyalty in Taking People's Business Credit

DOI : $\underline{\text { https://doi.org/10.37531/ecotal.v1i2.18 }}$

3) Analysis of the effect of $\mathrm{X} 3$ on $\mathrm{Y} 1$ shows a significance value of $0.030<0.05$ with a total effect of 0.232 . This indicates that the company's image has a significant positive effect on customer satisfaction. This makes H3 in this study accepted.

The results of this study support the results of previous research conducted by Khotimah (2018) which suggests that the company's image has a significant positive effect on customer satisfaction. This is because with a good corporate image it will trigger feelings of pleasure from consumers so that, by using the company's products, consumers will feel happy which encourages the creation of separate satisfaction for the consumers concerned.

The results of the study are in line with the opinion of Soemirat and Adianto (2007) who stated that the company's image is the impression, feeling and image of the public towards the company, the impression that is deliberately created from an object, person or organization.

To improve the company's image can be done in several ways. Some of them are by improving the image of the company (the Bank) in terms of choosing a strategic location so that it is easily accessible by consumers (or in this case customers). In addition, physical facilities can also attract the creation of customer satisfaction, where customers tend to be more interested in choosing a bank that has distinctive characteristics (physical facilities) for example the existence of a distinctive architecture that distinguishes the bank from other banks. And no less important is the friendly attitude of the employees can also improve the company's image in the eyes of customers

2) Analysis of the effect of $X 1$ on $Y 2$ shows a significance value of $0.001<0.05$ with a total effect of 0.392 . This indicates that the service has a significant positive effect on customer loyalty. This makes $\mathrm{H} 4$ in this study accepted.

These results support the results of research conducted by Wahyuni (2020) and Nitha \& Yusuf (2019) which shows that service provides a positive and significant impact on customer loyalty. This happens due to the good quality of service provided by the company, it can trigger customer convenience in conducting transactions with the company, because the community tends to be loyal if served well, politely, and comfortably. Thus, with this, it can significantly increase customer loyalty to remain a customer of PT. Bank Sulselbar (Nitha \& Yusuf, 2019; Octavia, 2019). The results of this study are in line with the opinion of Tjiptono and Chandra (2016) who define service quality as a dynamic condition associated with service products that are able to meet and or exceed the expectations of consumers who in this study are customers.

Volume 3 Issue 1 (2022)

Economics and Digital Business Review

ISSN: 2774-2563 (Online) 
Zulkifli Jamid $^{\otimes}$, Ria Mardiana ${ }^{2}$ Sabir $^{3}$

Analysis of Factors that Influence Customer Loyalty in Taking People's Business Credit

DOI : $\underline{\text { https://doi.org/10.37531/ecotal.v1i2.18 }}$

In this study it was also found that there are several aspects that make the service a positive and significant impact on customer loyalty, namely the existence of guarantees for all forms of transactions carried out between customers and the bank which guarantees that the activities carried out are safe. In addition, the services provided are also considered responsive in serving and responding to all forms of customer needs. These things make customer loyalty increase with the good service provided by the company.

3) Analysis of the effect of $\mathrm{X} 2$ on $\mathrm{Y} 2$ shows a significance value of $0.037<0.05$ with a total effect of 0.428 . This indicates that advertising has a significant positive effect on customer loyalty. This makes H5 in this study accepted.

The findings of this study are in line with research conducted by Paramananda \& Agus Satria (2015) showing that attractive advertisements presented by companies are considered to increase customer loyalty. (Paramananda \& Satria Pramudana, 2015). This happens because of the good quality of advertising about the company and providing the information needed by customers. In addition, the existence of good advertising can trigger a positive stigma of expectations in the minds of the public, so that when the information provided by the company is in accordance with what prospective customers want, then when the community has become a customer, they will become loyal because the company can fulfill its needs. the expectations desired by the customer in meeting their needs in managing their finances.

4) The analysis of the effect of $X 3$ on $Y 2$ shows a significance value of $0.089>0.05$ with a total effect of 0.319. This indicates that the company's image has no significant effect on customer loyalty. This makes H6 in this study rejected.

This means that the better the company's image can not increase loyalty. This finding is not in line with several studies that have been conducted where company image is considered as one aspect that can increase customer loyalty. This is because if a company has a good image in the eyes of the public, then the company is considered to be able to meet the needs of the public in terms of what they want. (Budianto, 2019; Khotimah, 2018; Nurudin, 2018).

However. The results in this study indicate the opposite, where company image has no significant effect in increasing customer loyalty. This can be indicated that the company's image is not the only aspect to increase customer loyalty at PT. Bank Sulselbar Makassar main branch. Where, to

Volume 3 Issue 1 (2022)

Economics and Digital Business Review

ISSN: 2774-2563 (Online) 
increase customer loyalty, companies tend to provide good service so that customers will remain loyal to the company.

5) Analysis of the effect of $Y 1$ on $Y 2$ shows a significance value of $0.001<0.05$ with a total effect of 0.392 . This indicates that the service has a significant positive effect on customer loyalty. This makes $\mathrm{H} 7$ in this study accepted.

This shows that the more satisfied customers, the more loyal customers of PT. Bank Sulselbar Makassar main branch. The results also show the respondents' responses to services at PT. Bank Sulselbar Makassar main branch shows the average respondent's response is good.

The results of this study are in line with research conducted by Octavia (2019), Nurudin (2018), and (Naim et al., 2019) which shows that satisfaction has a significant positive effect on customer loyalty. Where satisfaction becomes a variable with a higher level of relationship than the many existing variables. This proves that the level of satisfaction provides a significant guarantee for the loyalty of each customer in Bukopin Syariah banking. Satisfaction both in terms of service and product understanding. Satisfaction is considered to have a better guarantee in creating customer loyalty.

6) Analysis of the effect of $X 1$ through $Y 1$ on $Y 2$ shows that the direct effect given by $X 1$ to $Y 2$ is 0.327 . While the indirect effect of $\mathrm{X} 1$ on through $\mathrm{Y} 1$ on $\mathrm{Y} 2$ is the multiplication between the value of beta $\mathrm{X} 1$ and beta $\mathrm{Y} 1$ against $\mathrm{Z}$, which is $0.266 \mathrm{X} 0.326=0.087$. Then the total effect given by $\mathrm{X} 1$ to $\mathrm{Y} 2$ is the direct effect plus the indirect effect, namely $0.327+0.087=0.414$. Based on this, it is known that the direct influence value is 0.327 and the indirect effect is 0.087 , which means that the indirect effect is smaller than the direct effect. These results indicate that indirectly, service through customer satisfaction has no significant effect on customer loyalty, so H8 in this study is rejected.

This shows that the satisfaction variable cannot strengthen the relationship between the service variable and customer loyalty of PT. Bank Sulselbar Makassar main branch. This is not in accordance with the initial expectations of researchers where the better the quality of service owned by the company, the higher the satisfaction of a person in using the services of the company and has an impact on increasing customer loyalty. The results of this study do not support previous research as conducted by Raziq Aulia (2021), Octavia (2019), Trianah et al., (2017), 
Nurudin (2018), (Naim et al., 2019) which states that service has a significant positive effect on customer satisfaction, and customer satisfaction has a significant positive effect on customer loyalty.

Thus, it can be seen that service is not the only aspect to increase satisfaction that can trigger customer loyalty. However, there are several other important things such as product quality and good corporate governance of the company itself. The results of this study are not in line with previous studies which describe that service has a significant positive effect on customer loyalty through decisions as an intervening variable.

7) Analysis of the effect of $\mathrm{X} 2$ through $\mathrm{Y} 1$ on $\mathrm{Y} 2$ shows that the direct effect given by $\mathrm{X} 1$ to $\mathrm{Y} 1$ is 0.234 . While the indirect effect of $\mathrm{X} 1$ on through $\mathrm{Y} 1$ on $\mathrm{Y} 2$ is the multiplication between the value of beta X1 with beta $\mathrm{Y} 1$ against $\mathrm{Z}$ which is $0.299 \mathrm{X} 0.326=0.097$. Then the total effect given by X1 to $\mathrm{Y} 2$ is the direct effect plus the indirect effect, namely $0.234+0.097=0.331$. Based on this, it is known that the direct influence value is 0.234 and the indirect effect is 0.097 , which means that the indirect effect is smaller than the direct effect. These results indicate that indirectly, service through customer satisfaction does not have a significant effect on customer loyalty, so H9 in this study is rejected.

Thus, it can be indicated that the better the advertising carried out by PT. Bank Sulselbar Makassar main branch has not been able to significantly increase customer satisfaction which at the same time cannot increase their loyalty to the company. This is not in accordance with the researchers' initial expectations and at the same time not in line with previous studies conducted by Winarti (2016), Faizah (2017), and Sopiyan (2020), Nurudin (2018), (Naim et al., 2019), where advertising has a significant positive effect on satisfaction, and satisfaction can significantly increase customer loyalty

8) Analysis of the effect of $\mathrm{X} 3$ through $\mathrm{Y} 1$ on $\mathrm{Y} 2$ shows that the direct effect given by $\mathrm{X} 3$ to $\mathrm{Y} 1$ is 0.158 . While the indirect effect of $\mathrm{X} 3$ on through $\mathrm{Y} 1$ on $\mathrm{Y} 2$ is the multiplication between the value of beta X3 and beta Y1 against Y2, which is $0.280 \mathrm{X} 0.326=0.052$. Then the total effect given by $\mathrm{X} 1$ to $\mathrm{Y} 2$ is the direct effect plus the indirect effect, namely $0.158+0.052=0.210$. Based on this, it is known that the direct influence value is 0.158 and the indirect effect is 0.210 , which means that 
Zulkifli Jamid $^{\bowtie}$, Ria Mardiana ${ }^{2}$ Sabir $^{3}$

Analysis of Factors that Influence Customer Loyalty in Taking People's Business Credit

DOI : $\underline{\text { https://doi.org/10.37531/ecotal.v1i2.18 }}$

the indirect effect is greater than the direct effect. These results indicate that indirectly, service through customer satisfaction does not have a significant effect on customer loyalty, so H10 in this study is rejected.

Thus, it can be indicated that the corporate image of PT. Bank Sulselbar Makassar main branch, cannot increase customer satisfaction which can also trigger an increase in loyalty to the company. Although, the results of this study suggest that the company's image directly has a significant positive effect on satisfaction, but it does not have a significant effect on customer loyalty.

The results of this study are not in accordance with what was expected by the researchers, and also not in line with previous research where the company's image is one aspect that needs to be considered by the company in order to increase customer satisfaction which has an impact on increasing customer loyalty at PT. Bank Sulselbar Makassar main branch (Budianto, 2019; Khotimah, 2018; Naim et al., 2019; Nurudin, 2018).

\section{Conclusions}

Service, advertising and corporate image each have a significant positive effect on customer satisfaction, which means that the higher the level of service, advertising and company image, the higher the level of customer satisfaction. Service and advertising each has a significant positive effect on customer loyalty, which means that the higher the level of service and advertising, the higher the level of customer loyalty. While the company's image has no effect on consumer loyalty. This is because consumers have different characters so that their assessment of the company's image is carried out in different ways. Service, advertising and corporate image through customer satisfaction have no significant effect on customer loyalty. So that customer satisfaction does not necessarily guarantee loyalty.

\section{References :}

Aziza, A. M. (2010). Analisa Strategi Pemasaran Produk BLife InvestLink Syariah di Pt. Bank Sulselbar Life Insurance Divisi Syariah. Jakarta: Skripsi. UIN Syarif Hidayatullah.

Assagaff, S.I.U. (2014). Analisis Pengaruh Kualitas Pelayanan, Nilai Pelanggan, Kepuasan Pelanggan, serta Trust Terhadap Loyalitas Nasabah. Skripsi. Universitas Diponegoro budianto, E. (2019). Pengaruh Kualitas Pelayanan Dan Citra Perusahaan Terhadap Loyalitas Nasabah Pada Ajb Bumiputera. Jurnal Ilmu Keuangan Dan Perbankan (Jika). Https://Doi.Org/10.34010/Jika.V8i2.1934 
Donni Juni. 2017. Perilaku Konsumen: Dalam Persaingan Bisnis Kontemporer. Bandung: Cv. Alfabeta

Faizah, N. (2017). Pengaruh Citra Merek, Iklan, Suasana Toko Terhadap Loyalitas Konsumen Dimediasi Kepuasan Konsumen. Jurnal Ilmu Dan Riset Manajemen (Jirm).

Hidayat, Racmad. 2009. Pengaruh Kualitas,Kualitas Produk Dan Nilai Nasabah Terhadap Kepuasan Dan Loyalitas Nasabah Bank Mandiri. Dalam Jurrnal Manajemen Dan Kewirausahaan, 11(1): H: 59-72.

Khotimah, N. (2018). Pengaruh Religiusitas, Kepercayaan, Citra Perusahaan, Dan Sistem Bagi Hasil Terhadap Minat Nasabah Menabung Dan Loyalitas Di Bank Syariah Mandiri. Jurnal Ilmu Ekonomi \& Manajemen, 05(01), 37-48.

Kotler, Philip, (2012), Manajemen Pemasaran, Edisi Bahasa Indonesia, Jakarta: Salemba Empat Naim, R. N., Mus, A. R., Plyriadi, A., \& Bahari, F. (2019). Pengaruh Kualitas Layanan, Nila Dan Kepuasan Terhadap Loyalitas Nasabah Bank Syariah Bukopin Di Makasar. Center Of Economic Student Journal.

Naninsih, N., \& Hardiyono. (2019). Pengaruh Strategi Pemasaran Terhadap Kepuasan Dan Keputusan Pembelian Produk Usaha Kecil Menengah (Ukm) 310 Di Makassar. 1(1), 47-61.

Nitha, W. E., \& Yusuf, A. M. (2019). Pengaruh Kualitas Pelayanan Dan Customer Relationship Management Terhadap Loyalitas Nasabah Pada Bank Bjb Cabang Depok. Jurnal Ilmiah Binaniaga. Https://Doi.Org/10.33062/Jib.V14i1.304

Nurudin, N. . (2018). Pengaruh Relationship Marketing, Citra Perusahaan Dan Kepuasan Terhadap Loyalitas Nasabah (Studi Pada Bank Rakyat Indonesia Syariah Kantor Cabang Semarang)Pengaruh Relationship Marketing, Citra Perusahaan Dan Kepuasan Terhadap Loyalitas Nasabah (Studi. Jurnal Stie Semarang. Https://Doi.Org/10.33747/Stiesmg.V10i1.84

Octavia, R. (2019). Pengaruh Kualitas Pelayanan Dan Kepuasan Nasabah Terhadap Loyalitas Nasabah Pt. Bank Index Lampung. Jurnal Manajemen Pemasaran, 13(1). Https://Doi.Org/10.9744/Pemasaran.13.1.35-39

Paramananda, N., \& Satria Pramudana, K. (2015). Pengaruh Tarif Premi, Kualitas Pelayanan, Daya Tarik Iklan, Dan Citra Merek Terhadap Loyalitas Nasabah. E-Jurnal Manajemen Universitas Udayana.

Purwanti, E. (2011). Analisis Faktor-Faktor Pengambil Keputusan Pembelian Konsumen Pada Departement Store/Supermarket di Salatiga. Among Makarti. Vol. 4, No. 7 .

Raziq Aulia, M. (2021). Pengaruh Kualitas Layanan, Kepuasan Dan Religiusitas Terhadap Loyalitas Nasabah Bank Syariah Mandiri Cabang Banda Aceh. Jurnal Ilmiah Mahasiswa Ekonomi Manajemen

Soemirat, S dan Adianto. (2007). Dasar-dasar Public Relation. Jakarta: Remaja.

Sombolayuk, W., Sudirman, I., \& Yusuf, R. M. (2019). Pengaruh Modal Keuangan Terhadap Kinerja Perusahaan Ukm Melalui Strategi Inovasi (Studi Empiris Perusahaan UKM di Kota Makassar). Dinamika Akuntansi, Keuangan Dan Perbankan, 8(2), 134-157.

Sopiyan, P. (2020). Pengaruh Iklan Dan Citra Merek Terhadap Kepuasan Konsumen (Studi Pada Konsumen sepeda Motor Honda PT Helmi Hendra Motor Maja Majalengka). Entrepreneur: Jurnal Bisnis Manajemen Dan Kewirausahaan, 1(2). https://doi.org/10.31949/entrepreneur.v1i2.888 
Tjiptono, F., \& Candra, G. (2016). Pemasaran Jasa (Prinsip, Penerapan, dan Penelitian). Yogyakarta: Andi.

Trianah, L., Pranitasari, D., \& Zahrani Marichs, S. (2017). Pengaruh Kualitas Produk dan Kualitas Pelayanan Terhadap Kepuasan Pelanggan dan Loyalitas Pelanggan. Jurnal STEI Ekonomi, 26(01), 105-122. https://doi.org/10.36406/jemi.v26i01.201

Winarti, E. (2016). Pengaruh Kualitas Layanan, Iklan, dan Citra Merek terhadap Loyalitas Nasabah Bank Bukopin di Daerah Setiabudi Jakarta Selatan. Jurnal Ekonomi Dan Perbankan Vol 2. No. 22016 ISSN 2252 - 7886, 2(2). 